\title{
Is Stem Cell Therapy the Future of Orthopedics?
}

\author{
Hua Feng, MD \\ Sports Medicine Service, Beijing Jishuitan Hospital, Beijing, China
}

An increasing number of articles on the treatment effect of stem cell therapy have been published in the recent decade. Although the techniques in orthopedic surgery, such as total knee arthroplasty (TKA) and anterior cruciate ligament (ACL) reconstruction, have shown great improvement, the restoration of normal biomechanics $^{1)}$ and proprioception ${ }^{2)}$ is still the main issue. Hence the growing interest of researchers in regenerative medicine. Among the numerous methods that have been used for enhancing healing and regeneration, mesenchymal stem cell (MSC) therapy is one of the most commonly used strategies. MSCs have high proliferative potential and the ability to differentiate into chondrocytes, osteoblasts, and adipocytes ${ }^{3}$. In addition to their multilineage potential, MSCs have further therapeutic functions in response to injury, including immune modulation ${ }^{4)}$ and trophic activities ${ }^{5}$. The theme of this issue of the Knee Surgery \& Related Research is stem cells. The current issue contains three articles on this theme including one literature review article, one meta-analysis, and one original article. The literature review by Huri et al., outlined the latest advances and potential trends in using infrapatellar fat pad-derived stem cells (IPFP-ASCs) and their preclinical and clinical implications. The meta-analysis by Shin et al. synthesized 8 articles to assess clinical and magnetic resonance imaging (MRI) outcomes after surgery in patients with knee osteoarthritis (OA) treated with bone marrow-derived MSCs (BMMSCs). The other article compared the regenerative potential of ACL-derived MSCs (ACL-MSCs) from old donors with ACL-

Correspondence to: Hua Feng, MD

Sports Medicine Service, Beijing Jishuitan Hospital, Xinjiekoudongjie 31, Xicheng District, Beijing, China

Tel: +86-10-58516396

E-mail: fenghua20080617@126.com

This is an Open Access article distributed under the terms of the Creative Commons Attribution Non-Commercial License (http://creativecommons.org/licenses/by-nc/4.0/) which permits unrestricted non-commercial use, distribution, and reproduction in any medium, provided the original work is properly cited.
MSCs from young donors.

One of the most conflicting subjects, which was also discussed in 2 of the 3 articles in the current issue, is the effect of age on the availability, proliferative capacity, and potential for differentiation of MSCs ${ }^{4,6}$. In the literature review by Huri et al., the independence of the decrease of age-related stemness was the main advantage of IPFP-ASCs over BM-MSCs. Based on the theory that the quantity and quality of MSCs declines with aging, Block et al. ." $^{7}$ even proposed a method that "rejuvenated" elderly BM-MSCs. However, in the original article by Shin et al., they concluded that no substantial differences between ACL-MSCs from young and those from old donors were observed in their proliferative capacity and multilineage differentiation potential. Furthermore, as stated by another review ${ }^{3)}$, although aging appears to alter the differentiation potential of BM-MSCs measured in vitro, whether this occurs in vivo is still debatable.

Currently, the clinical application of MSCs in orthopedic field is mainly degenerative OA. Compared with the number of preclinical studies, the number of clinical trials is limited ${ }^{8}$. In the metaanalysis of Shin et al., patients treated with BM-MSCs showed significant functional improvement and pain relief when compared with baseline, although MRI findings did not show significant differences. After all, since there is a paucity of randomized controlled trials, there are still many questions to be answered in terms of the mechanism, best cell source, most appropriate processing method, most effective dose, delivery procedure, and long-term safety". In addition, although few articles on the application of MSCs in sports medicine field exist, the future of this field will be promising.

\section{References}

1. Duchman KR, Gao Y, Pugely AJ, Martin CT, Callaghan JJ. Differences in short-term complications between unicompartmental and total knee arthroplasty: a propensity score 
matched analysis. J Bone Joint Surg Am. 2014;96:1387-94.

2. Song GY, Zhang J, Li X, Li Y, Feng H. Biomechanical and biological findings between acute anterior cruciate ligament reconstruction with and without an augmented remnant repair: a comparative in vivo animal study. Arthroscopy. 2016; 32:307-19.

3. Baker N, Boyette LB, Tuan RS. Characterization of bone marrow-derived mesenchymal stem cells in aging. Bone. 2015;70:37-47.

4. Murray IR, Corselli M, Petrigliano FA, Soo C, Peault B. Recent insights into the identity of mesenchymal stem cells: Implications for orthopaedic applications. Bone Joint J. 2014; 96:291-8.

5. Caplan AI, Correa D. The MSC: an injury drugstore. Cell Stem Cell. 2011;9:11-5.

6. Ganguly P, El-Jawhari JJ, Giannoudis PV, Burska AN, Ponchel F, Jones EA. Age-related changes in bone marrow mes- enchymal stromal cells: a potential impact on osteoporosis and osteoarthritis development. Cell Transplant. 2017;26: 1520-9.

7. Block TJ, Marinkovic M, Tran ON, Gonzalez AO, Marshall A, Dean DD, Chen XD. Restoring the quantity and quality of elderly human mesenchymal stem cells for autologous cellbased therapies. Stem Cell Res Ther. 2017;8:239.

8. Choi S, Kim JH, Ha J, Jeong BI, Jung YC, Lee GS, Woo HM, Kang BJ. Intra-articular injection of alginate-microencapsulated adipose tissue-derived mesenchymal stem cells for the treatment of osteoarthritis in rabbits. Stem Cells Int. 2018; 2018:2791632.

9. Iturriaga L, Hernaez-Moya R, Erezuma I, Dolatshahi-Pirouz A, Orive G. Advances in stem cell therapy for cartilage regeneration in osteoarthritis. Expert Opin Biol Ther. 2018; 18:883-96. 